\title{
Global Shift: Mapping the Changing Contours \\ of the World Economy
}

\author{
by Peter Dicken \\ 7th edn, New York and London: Guilford Press, 2015 \\ ISBN 978-1-4625-1955-2 \\ Softcover $\$ 55,645$ pages
}

\section{Reviewed by Susan McDaniel \\ University of Lethbridge}

Global Shift is a big book with a big history (this is the seventh edition), on a big, ever-shifting topic with a big history itself. The first edition was published in 1985 as a self-described (by the author in the Preface) one-off attempt to make sense of changing geographies of the world economy. Clearly, that attempt appealed to readers, since here we are in the seventh edition. And it is easy to see why, as this review will elucidate.

Peter Dicken is a highly acclaimed Emeritus Professor of Economic Geography, School of Environment and Development, University of Manchester. The four principles that guide this volume are revealed in every chapter: (1) to be solidly empirical but not descriptive; (2) to theoretically and broadly engage with globalization ideas; (3) to connect current events with longer term processes; and (4) to acknowledge the complexities of globalization. This reviewer would add that this book, unlike much writing on globalization, is unequivocally interdisciplinary, giving it strength and depth of insight. And it has companion websites for both students and instructors that include more than the usual sets of discussion or test questions, also a wide array of additional readings and resources.

Structured into four sections (seventeen chapters), the book unfolds not only as highly engaging but as a true page-turner. Part One follows a lead chapter enticingly entitled "What in the World is Going On?" and focuses on a perpetually shifting global economic map, with changing centres of gravity. Part Two (chapters 3-6) explores the many complex ways in which actors, institutions, and processes that comprise the global economy interact to produce global production networks. This section examines how "gales of creative destruction" - set in motion by technological changes, increasingly complex networks, and changing relations of states with transnational corporations and other states-work to construct and reconstruct globalization. Part Three (chapters 7-11) - looks at winning and losing in the global economy, and impacts on people and places. Here, attention is given to the uneasy relations of transnationals to states, of environment to economies, of the local or national in seeing value in global networks, and how all might find ways to benefit. Part Four (chapters 12-17) brings previous discussions down to earth, with six case studies revealing how globalization processes operate differently in different contexts. The studies range from primary industries such as food production and mineral extraction to manufacturing as diverse as clothing and automobiles, to so-called advanced business, financial, logistical, and distribution services. Precisely how these very different economic sectors are configured 
and reconfigured with respect to state-private enterprise relations, labour/consumer relations, and technological pressures are further explained.

In the stage-setting chapter 1 , a series of crises over the past half-century is laid out, as well as two competing meanings of globalization: as structural changes in the global economy, and as an ideology of neo-liberalism and free marketism. These two contrasting meanings play out throughout the book like a Greek chorus. Pointed out clearly and sharply in this chapter is that the global economy is, in fact, not so much more open than it had been, but it is more connected, qualitatively transforming economic relations across geographies. Importantly this introductory chapter challenges what Dicken calls the "more egregious globalization myths," i.e., that the world is now flat or borderless, that global corporations rule the world, and that globalization is always bad or always good.

Perhaps the most compelling chapters in the book-since not every chapter in this giant tome can be given its due in this short review — are the last six, chapters 12-17. They bring global shifts to earth in examining changing economic relations in extractive industries, in agro-food, in clothing, automobiles, business services, and logistics/distribution. It is here that we see the heterogeneity of globalization, where the myths mentioned in chapter 1 are confirmed as false. For example, contrasting the global processes involved in extractive industries, in food production, in clothing industries, and in the automotive sector, it is apparent and the globe is far from flat and borderless, and that the globalization of economic relations in these sectors is both good and bad. It must be emphasized that Dicken does not contrast these sectors but treats each one in a separate chapter. Very briefly, change characterizes each of these sectors, but in different ways. Extractive industries (chapter 12) are both landed and material, and face extreme volatility in demand, and socio-political constraints on supply as well. Issues involved in global processes tend to be viewed through a techno-economic lens, but Dicken points out that states are very much involved across the world, particularly with oil resources, that he suggests are not so much "natural" as socio-cultural and political. Certainly that is the case, as he suggests, with the Alberta Oil Sands. In agrofood global processes (chapter 13), transnational producers and large retailers play a significant role, while states are generally relegated to a regulatory role. Unlike in extractive industries, in food production the global chains are often difficult to trace. Evidence for this is the horsemeat scandal in France not long ago. Clothing and fashion production (chapter 14) exemplify intractable issues in the global economy, as clothing production is highly global and very fragmented. Consumer demand is uncertain and risky. As well, social movements such as anti-sweatshop groups make escalating demands on production networks.

As a further example, the auto industry (chapter 15) is nothing if not changing. In recent NAFTA negotiations, one might be forgiven for thinking that vehicles are mainly assembled in the three NAFTA countries in order to supply the global market. Not so, given that China, a one-party state with business controlled largely by said party, is by far the world's largest producer of cars. And their cars are increasingly being exported, although this reviewer can attest from a recent trip to China that many, many Chinese-made cars, often big SUVs, are on the roads in that country. The role of the state clearly is widely different in these different auto production regimes. Interestingly, if auto production is ranked, Japan comes after China, with the US and South Korea tied for third place, at only 6.6 per cent of global auto production.

With the financial and business services (chapter 16), the situation is described by Dicken as a "global casino" (a term coined by Susan Strange), where large sums of money are played on the other side of the world while we might be sleeping, and affect our well-being and security even if we never play the game. These services provide the "wiring" for the global economy, and finance is one of the most controversial of all economic activities. With the 2008 financial crisis, tensions 
between states and markets became acute. International financial flows have reached an unprecedented level, and many escape any state awareness, let alone regulation. If all the innovative financial "products" are added into the mix, risks are intensified and spread more widely, as happened with the US below-prime mortgage paper bubble that sparked the global financial crisis. In this sector, the globe is more borderless than in other sectors, but still not flat. Corporate strategies are international and profit-oriented, driving up salaries in this sector to very high levels indeed. And connectivity permits concentration of services in large cities, most notably in London's 'The City' and New York's Wall Street. Meanwhile, lower-order financial services are off-shored to less costly labour markets.

Lastly, in chapter 17 Dicken considers logistics and distribution services, a sector less often the focus of global studies. It is thought perhaps that with global markets and greater connectivity, products will somehow be moved as if by magic. This is, however, a huge sector of the global economy. In microcosm, we see the challenges with online ordering of goods and their delivery where some companies manage far better than others. The central barrier to smooth operation of logistics is political, ie the complications of tariffs, customs and administration. There is further pressure for rapid delivery. Dicken shows, with his penchant for descriptive graphics, the immense complexity of distribution processes that complicate and at times compromise the prospect of off-shoring production. It is a remarkable exposé.

This is a very contemporary book, accessible, readable and enlightening. The spectacular explanatory graphics are worth a look all on their own. They are illuminating, deftly conceptualized to illustrate complex issues and their interconnections, and beautifully presented in colour. The book as well has a long list of up-to-date references (41 pages) with a small number of footnotes in each chapter. It also has a helpful de-coding list upfront for all the usual acronyms used in globalization discussions which can feel like alphabet soup. But Dicken generally notes as well the full names throughout the text prior to relying the acronym.

This new edition is truly a sprightly path through the thicket that is globalization or the world economy. It is a book highly accessible to all levels of readers, from undergraduates to scholars of globalization. In particular, it would be appropriate for courses and scholars in business/ management, economics, development studies, geography, political science, and sociology. For demography or population studies courses, the book provides a vital backdrop for understanding demographic change, although there is little here directly on population per se. Topics of population ageing, migration, and population growth are considered but not in much depth.

Global Shift: Mapping the Changing Contours of the World Economy, 7th edition, is more than a readable book. It is a page-turner, opening up complex questions page after page and turning them over for the reader in clear, expository language to reveal an exciting adventure that leaves the reader hungry for more. This is no small task for a doorstopper of a book on the challenging and wide-ranging topic of global change. It is a masterful work. 